\title{
Exhaled NO and assessment of anti-inflammatory effects of inhaled steroid: dose-response relationship
}

\author{
S.L. Jones*, P. Herbison", J.O. Cowan*, E.M. Flannery*, R.J. Hancox*, C.R. McLachlan*, D.R. Taylor*
}

Exhaled NO and assessment of anti-inflammatory effects of inhaled steroid: doseresponse relationship. S.L. Jones, P. Herbison, J.O. Cowan, E.M. Flannery, R.J. Hancox, C.R. McLachlan, D.R. Taylor. (C) ERS Journals Ltd 2002.

ABSTRACT: Exhaled nitric oxide (eNO) is an easily measured marker of airway inflammation. This study was undertaken to evaluate the usefulness of serial eNO in investigating the dose-response relationship for inhaled beclomethasone (BDP), and to compare eNO with other markers of airway inflammation.

Following withdrawal of inhaled corticosteroid (ICS) therapy, 65 patients entered a double-blind, parallel-group, placebo-controlled trial of 50, 100, 200 or $500 \mu \mathrm{g} \cdot \mathrm{BDP}^{-\mathrm{day}^{-1}}$ for eight weeks. eNO and spirometry were performed weekly and a hypertonic saline challenge with sputum induction was performed at the beginning and end of treatment.

The relationship between the dose of ICS and changes in eNO and forced expiratory volume in one second (FEV1) was linear at 1 week and at the end of treatment. A linear dose-response relationship was also seen for sputum eosinophils. Changes in eNO correlated significantly with changes in sputum eosinophils. Changes in the provocative dose of saline causing a 15\% fall in FEV1 saline did not differ across the treatment groups nor did they correlate with changes in other measurements.

Exhaled nitric oxide may be used to assess the dose-response relationship for the antiinflammatory effects of inhaled beclomethasone. The relationship found in this study was linear over the dose range $0-500 \mu \mathrm{g} \cdot \mathrm{day}^{-1}$ soon after commencing therapy and continued over time.

Eur Respir J 2002; 20: 601-608.
* Dept of Medical and Surgical Sciences and ${ }^{\#}$ Dept of Preventive and Social Medicine, Dunedin School of Medicine, University of Otago, Dunedin, New Zealand.

Correspondence: D.R. Taylor, Dept of Respiratory Medicine, Dunedin School of Medicine, University of Otago, PO Box 913, Dunedin, New Zealand. Fax: 6434747641

E-mail: robin.taylor@stonebow.otago. ac.nz

Keywords: Asthma, bronchial provocation tests, dose-response, eosinophils, inhaled corticosteroid, nitric oxide

Received: October 92001

Accepted after revision: April 32002

This study was funded by the Health Research Council of New Zealand and by an Otago Research Grant administered by the University of Otago. S.L. Jones was supported by a GlaxoSmithKline (GSK) research fellowship, and GSK provided an educational grant.
Inhaled corticosteroids (ICS) are the most effective treatment for airway inflammation in asthma [1]. Their use results in an improvement in symptoms and lung function, as well as in reductions in inflammatory cells in bronchial biopsies [2] and induced sputum [3]. As a result, airway hyperresponsiveness (AHR) is also reduced $[4,5]$. Current guidelines recommend the use of ICS therapy in all but the mildest asthma [6]. The guidelines are based on the assumption that treating airway inflammation leads to improvement in asthma control. However, several studies have demonstrated incongruities in the relationship between both symptoms and lung function and airway inflammation [7-9]. This raises questions as to whether the primary goal when using ICS is to achieve symptom control, optimise lung function, minimise airway inflammation or reduce AHR.

In the past, dose-response relationships for ICS have been described using symptoms and lung function as the main outcome variables. Although a dose-response relationship exists for these end points, it may plateau at a relatively low dose. Thus, there may be some difficulty in differentiating between the effects of adjacent doses $[1,10]$. Other studies have shown that dose-response relationships vary when other end points are used [11]. For example, much higher doses of ICS are required to control airway hyperresponsiveness than symptoms $[11,12]$. There are fewer data to clarify these relationships for airway inflammation, even though control of airway inflammation is the primary reason for administering these drugs. Such information might be clinically helpful in assessing the relative efficacy of different ICS doses and as a guide to optimising long-term therapy.

Exhaled nitric oxide (eNO) is a repeatable, easily measured marker of airway inflammation [13, 14]. High levels are seen in both steroid-naïve asthma [15] and during acute exacerbations [16, 17]. Furthermore, levels decrease following treatment with both inhaled $[3,18$, 19] and oral steroids [20]. These results suggest that eNO may be a useful end point in measuring the doseresponse relationship for the effect of ICS therapy on airway inflammation.

Recently the current authors have confirmed the usefulness of eNO measurements in predicting deterioration in asthma control when ICS are withdrawn [17]. In this follow-up study the aim was to evaluate the usefulness of serial eNO measurements in measuring the anti-inflammatory effects of different doses of inhaled beclomethasone (BDP), and to make comparisons 
with other end points including lung function, sputum eosinophils and AHR to hypertonic saline.

\section{Methods}

\section{Subjects}

Patients with mild-to-moderate asthma [21] on maintenance ICS therapy were recruited. Patients were excluded (because the study involved withdrawal of ICS treatment) if they had a history of acute asthma requiring hospital admission, asthma characterised by sudden attacks, or had used oral prednisone during the previous 3 months.

\section{Study design}

Following run-in, ICS therapy was discontinued. Patients were reviewed weekly until "loss of control" developed, or for a maximum of 6 weeks. Those who did not develop loss of control were then withdrawn. Loss of control was defined by predetermined criteria [17] consisting of: 1) a fall in the mean (over the last 7 days) morning peak expiratory flow rate (PEFR) of $>10 \%$ from baseline, or a fall in either morning or evening PEFR on two consecutive days to $\leqslant 80 \%$ of baseline; or 2) mean daily bronchodilator use of $>3$ puffs longer than during run-in; or 3) nocturnal wakening with asthma symptoms on $\geqslant 3$ nights. week $^{-1}$ greater than during the run-in; or 4) asthma symptoms which were disagreeable or distressing.

Following loss of control, patients received $20 \mathrm{mg}$ prednisone orally for 2 days in order to alleviate their deteriorating symptoms. Although this may theoretically have influenced interpretation of subsequent ICS effects at 1 week, this strategy was necessary for reasons of safety. Patients were randomised to receive double-blind ICS treatment for 8 weeks, taking one puff from two identical metered-dose inhalers (Autohaler; 3M Pharmacueticals, St Paul, MN, USA) labelled "morning" and "evening". The treatments were: placebo (placebo twice daily (b.i.d)); $50 \mu \mathrm{g} \cdot \mathrm{day}^{-1}$ (50 $\mu \mathrm{g}$ BDP in the morning, placebo at night); $100 \mu \mathrm{g} \cdot \mathrm{day}^{-1}(100 \mu \mathrm{g}$ BDP in the morning, placebo at night); $200 \mu \mathrm{g} \cdot \mathrm{day}^{-1}$ $\left(100 \mu \mathrm{g}\right.$ BDP b.i.d); $500 \mu \mathrm{g} \cdot \mathrm{day}^{-1}(250 \mu \mathrm{g}$ BDP b.i.d).

Those patients who experienced significant worsening of their asthma while taking the randomised medication were withdrawn from that treatment group, given $20 \mathrm{mg}$ prednisone orally for a further 2 days, and entered into an open label treatment arm of $1,000 \mu \mathrm{g} \cdot \mathrm{day}^{-1}(2 \mathrm{puffs}$ of $250 \mu \mathrm{g}$ BDP $b . i . d)$.

Following randomisation (visit 1), patients were reviewed weekly for the first 4 weeks (visits 2-5) and then at the end of treatment ( 8 weeks, visit 6 ). Those patients whose ICS dose needed to be increased to $1,000 \mu \mathrm{g} \cdot \mathrm{day}^{-1}$ were also reviewed weekly for 4 weeks and again at the end of 8 week's treatment.

\section{Study procedures}

Diurnal PEFR, bronchodilator use and symptom scores were recorded on a daily record card.
Measurements of eNO and spirometry were made at each study visit and a hypertonic saline challenge with sputum induction was performed at the beginning and end of treatment.

Exhaled nitric oxide. eNO was measured prior to all other study procedures using a calibrated chemiluminescence analyser with on-line measurement of single exhalations according to a standard protocol $[13,14]$, with the exception of flow rate $\left(250 \mathrm{~mL} \cdot \mathrm{s}^{-1}\right)$ (the study was commenced prior to the publication of consensus guidelines). eNO levels were read at the plateau corresponding to $70-80 \%$ of the carbon dioxide curve. These readings were made at a later date by a person blinded to the patient's clinical status.

Hypertonic saline challenge. AHR to hypertonic saline $(4.5 \%)$ was measured using a modified standardised protocol [22, 23]. Spirometry was performed $1 \mathrm{~min}$ after each saline nebulisation. The challenge was discontinued when a $20 \%$ fall in forced expiratory volume in one second (FEV1) occurred or a cumulative inhalation time of 20 min was reached. The PD15 was calculated as the cumulative provocation dose of saline causing a $15 \%$ fall in FEV1.

Sputum induction. During the hypertonic saline challenge patients were encouraged to produce sputum between nebulisations. If a $20 \%$ fall in FEV1 occurred before an adequate sputum sample was obtained, inhaled salbutamol was administered and sputum induction was continued for a maximum cumulative time of $20 \mathrm{~min}$. Once an adequate sputum sample was obtained the whole specimen (sputum plus saliva) was analysed using a standardised method [24]. Cell viability was assessed by the trypan blue exclusion test, and a cell count was performed by haemocytometer. Cytospin slides were stained with May-Grunwald-Giemsa stain and a total of 400 nonsquamous cells were counted on two occasions. Where the difference between the two counts was $>10 \%$ for any cell type then the count was repeated twice and the mean for all four was recorded.

\section{Ethical considerations and safety}

Each patient's asthma control was monitored closely throughout the study. For ethical reasons, loss of control criteria included symptoms that were "disagreeable or distressing" irrespective of PEFR changes. All patients were provided with an individualised self-management plan, an emergency card, and a supply of prednisone tablets. Patients had 24-h access to one of the study investigators via the hospital paging system. In addition, recognising that ICS withdrawal had the potential to result in poor asthma control, each patient was telephoned by a study investigator on days 1 and 3 following randomisation. Ethical approval was obtained from the Otago Ethics Committee and informed consent was obtained from all study participants. 


\section{Statistical analysis}

The primary outcome of the study was to assess whether a dose-response relationship exists between inhaled corticosteroid dose in the range $0-500 \mu \mathrm{g} \cdot \mathrm{day}^{-1}$ and changes in eNO. Comparisons were made with sputum eosinophils, FEV1 and PD15 saline. Data were analysed on an intention-to-treat basis using analysis of covariance, adjusting for values at randomisation and for patients who for reasons of safety were later switched during the active treatment phase to receive $1000 \mu \mathrm{g} \cdot \mathrm{day}^{-1}$. Polynomial contrasts were fitted across the randomisation groups to establish the nature of the dose-response relationships. PD15 saline values were analysed as doubling-dose change from baseline. Estimated marginal means were calculated, and post-hoc analysis of pairwise between-dose comparisons were made, with Bonferroni adjustments for multiple comparisons. Pearson's correlations were calculated to assess the relationship between eNO, sputum eosinophils, FEV1 and PD15 saline at randomisation and at the end of the study.

At the time the study was designed there was no information on which to make power calculations. Based on anecdotal evidence it was calculated that 15 patients per group would offer $>80 \%$ power to detect a difference of $>0.8 \mathrm{sD}$ between groups. Although this afforded sufficient power to detect a linear trend across the groups, this was not determined a priori.

\section{Results}

\section{Randomisation}

Eighty-seven patients entered the study. Three patients withdrew consent prior to ICS withdrawal. Sixty-five patients $(77 \%)$ developed loss of control and were randomised into one of the five treatment groups. Demographic data are given in table 1. Data for study end points measured at baseline (before withdrawal of ICS, visit 0) and at randomisation (visit 1) are shown in table 2 .

\section{Treatment withdrawals}

One patient randomised to receive $500 \mu \mathrm{g} \cdot \mathrm{day}^{-1}$ was withdrawn at visit 1 due to the severity of their asthma, and was not considered further in the analysis. Twenty-five of the remaining 64 patients developed worsening of their asthma after randomisation and were entered into the open-label $1,000 \mu \mathrm{g} \cdot \mathrm{day}^{-1}$ arm of the study. The number of patients withdrawn from each of the treatment groups was six, five, eight, four, and two in the placebo, 50, 100,200 , and $500 \mu \mathrm{g} \cdot \mathrm{day}^{-1} \mathrm{BDP}$ groups, respectively. Comparisons between those who withdrew from the randomised treatment arm and those who completed treatment are shown in table 2. There were no significant differences between these two groups for eNO, sputum eosinophils or PD15 saline at the time of randomisation. Those who withdrew had a lower FEV1 \% predicted than those who did not withdraw (73.9 versus $82.5 \%$, respectively, $\mathrm{p}=0.005$ ). Those who withdrew also had a higher dose of maintenance ICS at study entry (mean $(95 \%$ confidence interval (CI) $776(635-917) \mu \mathrm{g} \cdot \mathrm{day}^{-1}$ and $614(536-694) \mu \mathrm{g} \cdot \mathrm{day}^{-1}$ respectively, $\mathrm{p}=0.042$ ).

\section{Dose-responses}

Changes in eNO and FEV1 (at 1 week and at the end of treatment) and in sputum eosinophils, and

Table 1.-Demographic data for the randomised study participants

\begin{tabular}{|c|c|c|c|c|c|c|}
\hline & \multirow[t]{2}{*}{ Total } & \multicolumn{5}{|c|}{ Treatment group } \\
\hline & & Placebo & $50 \mu \mathrm{g} \cdot \mathrm{day}^{-1}$ & $100 \mu \mathrm{g} \cdot \mathrm{day}^{-1}$ & $200 \mu \mathrm{g} \cdot \mathrm{day}^{-1}$ & $500 \mu \mathrm{g} \cdot \mathrm{day}^{-1}$ \\
\hline Number of patients $n$ & 65 & 13 & 14 & 14 & 12 & 12 \\
\hline $\begin{array}{l}\text { Number switched } \\
\text { to } 1000 \mu \mathrm{g} \cdot \text { day }^{-1}\end{array}$ & 25 & 6 & 5 & 8 & 4 & 2 \\
\hline Male:female & $22: 43$ & $4: 9$ & $6: 8$ & $7: 7$ & $2: 10$ & 3:9 \\
\hline Age yrs (range) & $\begin{array}{c}42.4 \\
(19-64)\end{array}$ & $\begin{array}{c}42.5 \\
(19-61)\end{array}$ & $\begin{array}{c}43.3 \\
(19-63)\end{array}$ & $\begin{array}{c}44.7 \\
(21-59)\end{array}$ & $\begin{array}{c}41.2 \\
(24-60)\end{array}$ & $\begin{array}{c}39.6 \\
(19-64)\end{array}$ \\
\hline $\begin{array}{l}\text { Duration of asthma } \\
\text { yrs (range) }\end{array}$ & $\begin{array}{c}27.0 \\
(4-60)\end{array}$ & $\begin{array}{c}30.3 \\
(4-60)\end{array}$ & $\begin{array}{c}30.6 \\
(6-60)\end{array}$ & $\begin{array}{c}22.5 \\
(4-48)\end{array}$ & $\begin{array}{c}31.2 \\
(12-55)\end{array}$ & $\begin{array}{r}20.2 \\
(4-40)\end{array}$ \\
\hline Skin test positive $\mathrm{n}(\%)$ & $60(92.3)$ & $12(92.3)$ & $14(100)$ & $12(85.7)$ & $12(100)$ & $10(83.3)$ \\
\hline Exsmokers:nonsmokers & $9: 56$ & $2: 11$ & $1: 13$ & $2: 12$ & $1: 11$ & 3:9 \\
\hline $\begin{array}{l}\text { ICS dose } \mu \mathrm{g} \cdot \text { day }^{-1} \\
\text { (BDP equivalent) }\end{array}$ & $\begin{array}{c}658 \\
(100-1600)\end{array}$ & $\begin{array}{c}731 \\
(100-1600)\end{array}$ & $\begin{array}{c}550 \\
(200-1000)\end{array}$ & $\begin{array}{c}700 \\
(200-1600)\end{array}$ & $\begin{array}{c}671 \\
(200-1000)\end{array}$ & $\begin{array}{c}642 \\
(200-1000)\end{array}$ \\
\hline FEV1 L & $\begin{array}{c}2.81 \\
(2.61-3.00)\end{array}$ & $\begin{array}{c}2.50 \\
(2.07-2.94)\end{array}$ & $\begin{array}{c}2.91 \\
(2.39-3.45)\end{array}$ & $\begin{array}{c}2.94 \\
(2.42-3.45)\end{array}$ & $\begin{array}{c}2.62 \\
(2.15-3.09)\end{array}$ & $\begin{array}{c}3.04 \\
(2.60-3.48)\end{array}$ \\
\hline FEV1 \% pred & $\begin{array}{c}90.8 \\
(86.3-95.2)\end{array}$ & $\begin{array}{c}83.7 \\
(71.3-96.1)\end{array}$ & $\begin{array}{c}91.0 \\
(82.1-99.8)\end{array}$ & $\begin{array}{c}91.9 \\
(82.2-101.5)\end{array}$ & $\begin{array}{c}85.2 \\
(71.6-98.8)\end{array}$ & $\begin{array}{c}102.5 \\
(93.9-111.0)\end{array}$ \\
\hline $\mathrm{FEV}_{1} / \mathrm{FVC} \%$ & $\begin{array}{c}70.8 \\
(68.1-73.6)\end{array}$ & $\begin{array}{c}68.3 \\
(59.5-77.1)\end{array}$ & $\begin{array}{c}70.6 \\
(64.4-76.7)\end{array}$ & $\begin{array}{c}69.1 \\
(62.2-76.0)\end{array}$ & $\begin{array}{c}69.7 \\
(63.2-76.3)\end{array}$ & $\begin{array}{c}76.9 \\
(72.2-81.5)\end{array}$ \\
\hline
\end{tabular}

Data are presented as mean (95\% confidence intervals) unless otherwise stated. ICS: inhaled corticosteroids; BDP: beclomethasone; FEV1: forced expiratory volume in one second; FVC: forced vital capacity. 
Table 2. - Data for study end-points measured at baseline (visit (V) 0) and at randomisation (V1)

\begin{tabular}{|c|c|c|c|c|c|c|c|c|c|}
\hline & \multirow{2}{*}{$\begin{array}{c}\text { Subjects } \\
\text { n }\end{array}$} & \multicolumn{2}{|c|}{ eNO ppb } & \multicolumn{2}{|c|}{ FEV1 \%pred } & \multicolumn{2}{|c|}{ Sputum eosinophils $\%$} & \multicolumn{2}{|c|}{ PD15 saline $\mathrm{mL}$} \\
\hline & & V0 & V1 & V0 & V1 & V0 & V1 & V0 & V1 \\
\hline \multicolumn{10}{|l|}{ Treatment group } \\
\hline Placebo & 13 & $\begin{array}{c}9.6 \\
(6.4-12.7)\end{array}$ & $\begin{array}{c}20.9 \\
(12.2-29.6)\end{array}$ & $\begin{array}{c}85.4 \\
(72.1-98.8)\end{array}$ & $\begin{array}{c}82.0 \\
(67.8-96.3)\end{array}$ & $\begin{array}{c}4.8 \\
(0-12.6)\end{array}$ & $\begin{array}{c}6.0 \\
(2.1-9.9)\end{array}$ & $\begin{array}{c}17.0 \\
(8.2-25.8)\end{array}$ & $\begin{array}{c}12.5 \\
(3.5-21.5)\end{array}$ \\
\hline $50 \mu \mathrm{g} \cdot \mathrm{day}^{-1}$ & 14 & $\begin{array}{c}11.6 \\
(6.8-16.3)\end{array}$ & $\begin{array}{c}22.1 \\
(14.0-30.2)\end{array}$ & $\begin{array}{c}87.5 \\
(76.2-98.8)\end{array}$ & $\begin{array}{c}77.7 \\
(66.1-89.3)\end{array}$ & $\begin{array}{c}3.6 \\
(0-7.9)\end{array}$ & $\begin{array}{c}10.0 \\
(0.7-19.3)\end{array}$ & $\begin{array}{c}15.0 \\
(8.6-21.4)\end{array}$ & $\begin{array}{c}11.0 \\
(3.6-18.4)\end{array}$ \\
\hline $100 \mu \mathrm{g} \cdot \mathrm{day}^{-1}$ & 14 & $\begin{array}{c}13.8 \\
(7.3-20.3)\end{array}$ & $\begin{array}{c}32.1 \\
(18.8-45.4)\end{array}$ & $\begin{array}{c}91.4 \\
(81.4-101.5)\end{array}$ & $\begin{array}{c}75.1 \\
(65.7-84.5)\end{array}$ & $\begin{array}{c}8.5 \\
(0-18.2)\end{array}$ & $\begin{array}{c}31.9 \\
(15.3-48.6)\end{array}$ & $\begin{array}{c}15.9 \\
(7.0-24.7)\end{array}$ & $\begin{array}{c}13.3 \\
(5.4-21.2)\end{array}$ \\
\hline $200 \mu \mathrm{g} \cdot \mathrm{day}^{-1}$ & 12 & $\begin{array}{c}11.3 \\
(7.9-14.7)\end{array}$ & $\begin{array}{c}29.9 \\
(13.3-46.6)\end{array}$ & $\begin{array}{c}89.0 \\
(76.1-101.9)\end{array}$ & $\begin{array}{c}73.9 \\
(59.7-88.1)\end{array}$ & $\begin{array}{c}1.4 \\
(0.5-2.2)\end{array}$ & $\begin{array}{c}16.4 \\
(3.8-29.0)\end{array}$ & $\begin{array}{c}20.1 \\
(11.4-28.9)\end{array}$ & $\begin{array}{c}8.4 \\
(1.9-14.8)\end{array}$ \\
\hline $500 \mu \mathrm{g} \cdot \mathrm{day}^{-1}$ & 12 & $\begin{array}{c}11.4 \\
(4.4-18.3)\end{array}$ & $\begin{array}{c}25.2 \\
(12.6-37.8)\end{array}$ & $\begin{array}{c}100.2 \\
(92.2-108.2)\end{array}$ & $\begin{array}{c}87.9 \\
(75.2-100.5)\end{array}$ & $\begin{array}{c}1.9 \\
(0.1-3.8)\end{array}$ & $\begin{array}{c}22.8 \\
(3.6-42.1)\end{array}$ & $\begin{array}{c}15.7 \\
(8.0-23.5)\end{array}$ & $\begin{array}{c}13.2 \\
(3.5-22.8)\end{array}$ \\
\hline Completed & 40 & & $\begin{array}{c}24.6 \\
(18.5-30.8)\end{array}$ & & $\begin{array}{c}82.5 \\
(76.4-88.6)\end{array}$ & & $\begin{array}{c}17.8 \\
(10.4-25.3)\end{array}$ & & $\begin{array}{c}12.1 \\
(8.0-16.1)\end{array}$ \\
\hline Withdrew & 25 & & $\begin{array}{c}28.2 \\
(19.6-36.8)\end{array}$ & & $\begin{array}{c}73.9 \\
(64.9-82.9)\end{array}$ & & $\begin{array}{c}17.3 \\
(7.5-27.2)\end{array}$ & & $\begin{array}{c}11.8 \\
(5.8-16.8)\end{array}$ \\
\hline
\end{tabular}

Data are presented as mean (95\% confidence interval). eNO: exhaled nitric oxide; FEV1: forced expiratory volume in one second; PD15 saline: the cumulation provocative dose of saline causing a $15 \%$ fall in FEV 1 .

PD15 saline (at the end of treatment) are shown in figs. 1 and 2, respectively.

There was a significant linear relationship between ICS dose and each of the following: changes in eNO at 1 week and end of treatment $(\mathrm{p}=0.022$ and $\mathrm{p}=0.015$, respectively); changes in FEV1 at 1 week and end of treatment $(\mathrm{p}=0.043$ and $\mathrm{p}=0.006$, respectively); and changes in sputum eosinophils at the end of treatment $(\mathrm{p}=0.037)$. There was no significant relationship between ICS dose and the change in PD15 saline. All of these comparisons were adjusted for baseline measurements and changes in numbers due to withdrawals. When those entering the $1,000 \mu \mathrm{g} \cdot \mathrm{day}^{-1}$ arm were excluded from the analysis the significance of the linear relationship seen across the groups for changes in eNO persisted $(\mathrm{p}=0.003)$, however, the linear relationship seen with FEV1 and sputum eosinophils became nonsignificant.

In assessing the between-dose effects of ICS therapy, pairwise comparisons for each of the treatment groups were performed. There were significant differences in eNO between $100 \mu \mathrm{g} \cdot \mathrm{day}^{-1}$ and both 200 and $500 \mu \mathrm{g} \cdot$ day $^{-1}$ at 1 week $\left(\mathrm{p}<0.05\right.$ for each), and between $500 \mu \mathrm{g} \cdot \mathrm{day}^{-1}$ and both placebo and $100 \mu \mathrm{g} \cdot \mathrm{day}^{-1}$ and at the end of treatment $(p=0.01$ and $p=0.023$, respectively). For FEV1, there was a significant difference between $500 \mu \mathrm{g} \cdot \mathrm{day}^{-1}$ and placebo at the end of treatment $(p=0.04)$ but not for any of the other between-dose comparisons. Likewise, the only significant difference in sputum eosinophils with treatment occurred between $100 \mu \mathrm{g} \cdot \mathrm{day}^{-1}$ and $500 \mu \mathrm{g} \cdot \mathrm{day}^{-1}(\mathrm{p}=0.049)$. No other significant differences were found using pairwise comparisons. There were no significant differences in PD15 saline between treatments.

\section{Correlations between inflammatory markers}

Correlations between eNO, sputum eosinophils, PD15 saline and FEV1 \% pred at baseline and following treatment (expressed as absolute values and as changes from baseline) are shown in table 3 . Significant correlations were found between eNO and sputum eosinophils throughout the study. Also, changes in eNO correlated significantly with changes in sputum eosinophils. Changes in PD15 saline did not correlate with changes in any of the other markers.

\section{Discussion}

In this study it has been demonstrated that eNO measurements provide useful information regarding the dose-response relationship for the anti-inflammatory effects of ICS. This has potential practical importance not only to facilitate the monitoring of antiinflammatory treatment in individual patients, but also in assessing the efficacy of different inhaled corticosteroids at different doses. A significant linear relationship between the change in eNO and the dose of ICS used (over a range 0-500 $\mu \mathrm{g} \cdot \mathrm{day}^{-1}$ of BDP) was found in patients with moderate bronchial asthma in whom ICS had been withdrawn and loss of control occurred. This ensured that airway inflammation was sufficient for anti-inflammatory effects to be measured. The linear dose-response relationship was significant as early as 1 week after commencing therapy, and continued to 8 weeks, indicating that eNO measurements are not only rapidly responsive to changes in airway inflammation but that they also reflect the ongoing anti-inflammatory action of ICS therapy with time. A similar linear dose-response relationship was also found with FEV1 at 1- and 8-week's treatment. In a recently reported investigation SILKOFF et al. [25] have also demonstrated a stepwise decrease in eNO over a dose range of $0-800 \mu \mathrm{g} \cdot \mathrm{BDP} \cdot \mathrm{day}^{-1}$ in patients with elevated levels of eNO. The results of the present study go further. The highly significant correlation between changes in eNO and changes in sputum eosinophils, together with a linear dose-response relationship between ICS dose and changes in sputum eosinophils at the end of treatment confirm that the 

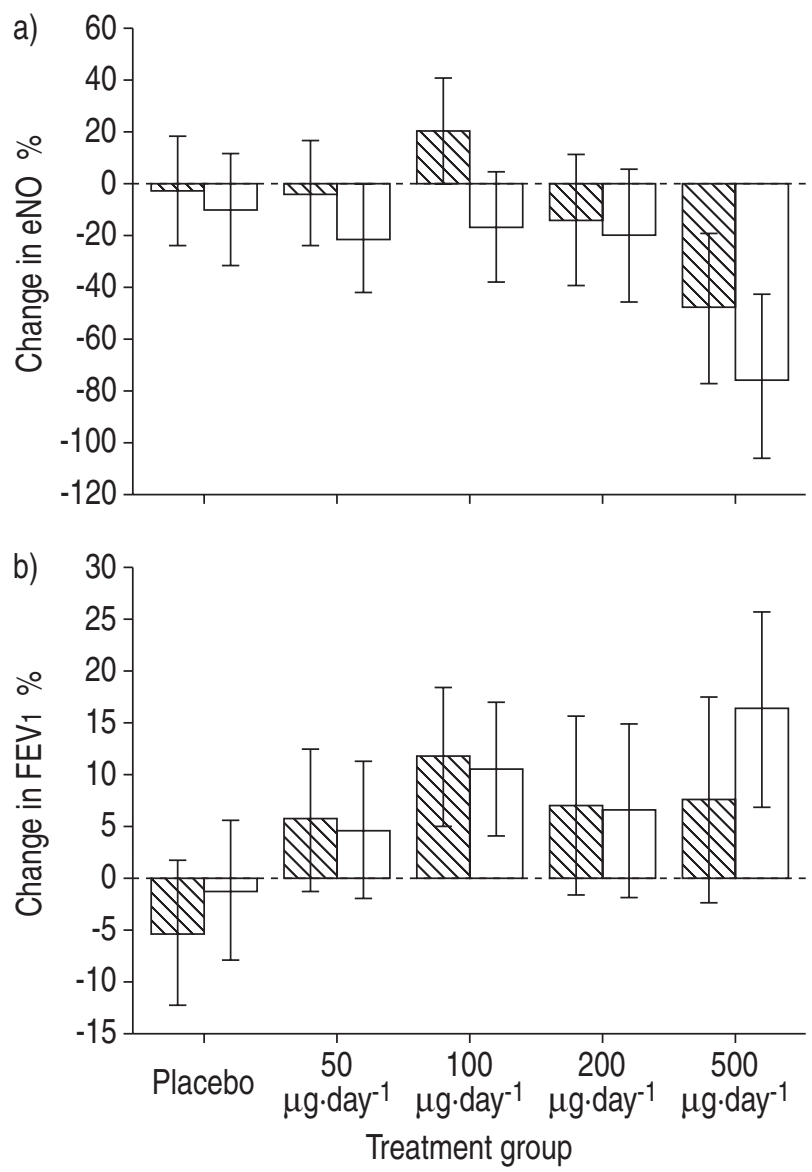

Fig. 1.- Percentage change in a) exhaled nitric oxide (eNO) and b) forced expiratory volume in one second $\left(\mathrm{FEV}_{1}\right)$ after 1 week $(\mathbb{\mathbb { N }})$ and at the end of the 8 weeks $(\square)$ of inhaled corticosteroid treatment. Data are presented as mean $\pm 95 \%$ confidence intervals. Data were derived from all patients, but adjusted for differences in baseline measurements and the numbers of patients remaining in the group at each time point. a) There was a significant difference across treatments at 1 week $(\mathrm{p}=0.005)$ and at the end of treatment $(\mathrm{p}=0.015)$. These differences were linear $(\mathrm{p}=0.022$ and $\mathrm{p}=0.003$, respectively). b) There was a significant difference across treatment groups at 1 week $(\mathrm{p}=0.014)$ and at the end of treatment $(\mathrm{p}=0.036)$. These differences were linear $(\mathrm{p}=0.043$ and $\mathrm{p}=0.006$, respectively).

dose-related decreases occurring in eNO correspond to a reduction in airway inflammation and provide validation of the primary outcome of the study.

It has been shown previously that changes occurring in eNO are seen in association with changes in other markers of airway inflammation following treatment with inhaled budesonide [26] and fluticasone [3]. However, the present study is the largest to date in which dose-dependency for these anti-inflammatory effects has been investigated. WILSON and LIPWORTH [27] have reported that at doses of $>400 \mu \mathrm{g}$ budesonide daily (the first step in their dose-ranging study for budesonide), no further reduction in eNO occurred despite further dose-related improvements in FEV1 and sputum eosinophil cationic protein. In a smaller study, JATAKANON et al. [28] reported that despite continuing reductions in sputum eosinophils at doses up to $1,600 \mu \mathrm{g}$ budesonide $\cdot \mathrm{day}^{-1}$, changes in eNO reached a plateau at $400 \mu \mathrm{g} \cdot \mathrm{day}^{-1}$. In contrast, in the
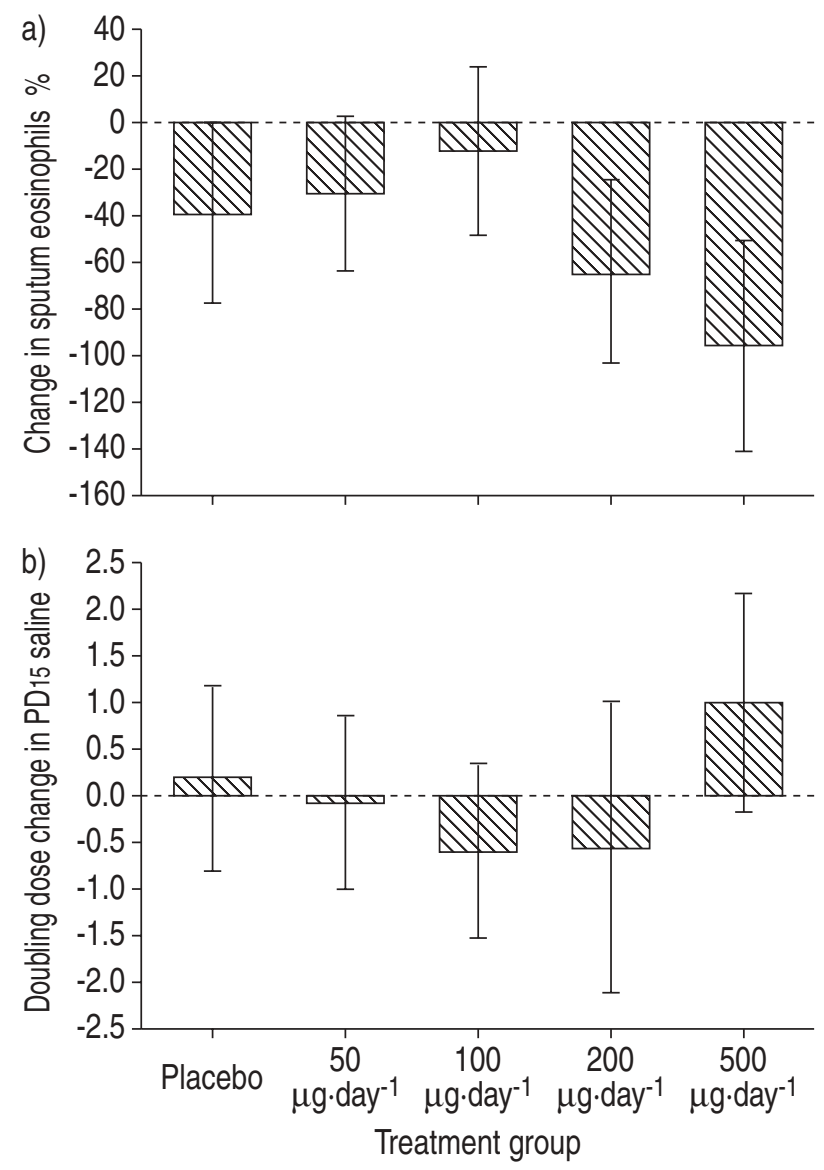

Fig. 2.-a) Percentage change in sputum eosinophils at the end of treatment. There was a significant linear relationship across the treatment groups $(\mathrm{p}=0.037)$. b) Doubling dose changes in cumulative provocative dose of saline causing a $15 \%$ fall in forced expiratory volume in one second (PD15 saline) at the end of treatment. No significant differences were seen across the treatment groups $(\mathrm{p}=0.837)$. Data are presented as means $\pm 95 \%$ confidence intervals. Data are derived from all patients, but adjusted for baseline measurements and the numbers of patients remaining in the group at each time point.

present study the dose-response relationship between eNO and ICS was linear and there was no evidence of a plateau over the range of doses studied $\left(0-500 \mu \mathrm{g} \cdot \mathrm{day}^{-1}\right)$, with similar outcomes observed for both sputum eosinophils and FEV1. However, the current study is not able to offer comment on whether or not a plateau to the dose-response relationship occurs with doses $>500 \mu \mathrm{g} \cdot \mathrm{day}^{-1}$.

The apparent conflict between these results and those of previous studies may be due to differences in asthma severity at the time of the investigation. In the current study, treatment was withdrawn until loss of control occurred and those who did not exhibit loss of control were excluded. A similar study design has been used by other investigators when evaluating the doseresponse for ICS [29, 30]. The rationale for this approach is that the therapeutic ratio for ICS may be influenced by asthma severity: patients with milder asthma may have little room for improvement. This may have influenced the results of previous studies $[27,28]$. This is supported further by the findings 
Table 3. - Correlations between various markers of airway inflammation and lung function

\begin{tabular}{lccc}
\hline Correlation & Visit 1 & Visit 6 & $\Delta$ Visit (6-1) \\
\hline eNO versus & $\mathrm{r}=0.519$ & $\mathrm{r}=0.548$ & $\mathrm{r}=0.403$ \\
\% eosinophils & $\mathrm{p}<0.001^{\#}$ & $\mathrm{p}<0.001^{\#}$ & $\mathrm{p}=0.002^{\#}$ \\
eNO versus & $\mathrm{r}=-0.352$ & $\mathrm{r}=-0.270$ & $\mathrm{r}=-0.192$ \\
PD15 saline & $\mathrm{p}=0.003^{\#}$ & $\mathrm{p}=0.051$ & $\mathrm{p}=0.187$ \\
eNO versus & $\mathrm{r}=-0.169$ & $\mathrm{r}=0.021$ & $\mathrm{r}=-0.252$ \\
FEV1\% pred & $\mathrm{p}=0.125$ & $\mathrm{p}=0.870$ & $\mathrm{p}=0.045^{\#}$ \\
\% eosinophils versus & $\mathrm{r}=-0.254$ & $\mathrm{r}=-0.185$ & $\mathrm{r}=0.045$ \\
PD15 saline & $\mathrm{p}=0.040^{\#}$ & $\mathrm{p}=0.204$ & $\mathrm{p}=0.771$ \\
\% eosinophils versus & $\mathrm{r}=-0.262$ & $\mathrm{r}=0.015$ & $\mathrm{r}=-0.585$ \\
FEV1\% pred & $\mathrm{p}=0.023^{\#}$ & $\mathrm{p}=0.913$ & $\mathrm{p}<0.001^{\#}$ \\
PD15 saline versus & $\mathrm{r}=0.420$ & $\mathrm{r}=0.533$ & $\mathrm{r}=-0.092$ \\
FEV1\% pred & $\mathrm{p}<0.001^{\#}$ & $\mathrm{p}<0.001^{\#}$ & $\mathrm{p}=0.529$ \\
\hline
\end{tabular}

eNO: exhaled nitric oxide; PD15 saline: cumulative provocative dose of saline causing a $15 \%$ fall in forced expiratory volume in one second (FEV 1 ).

of Silkoff et al. [25] who noted that patients with higher baseline eNO demonstrated dose-response reductions over a higher dose range $\left(0-800 \mu \mathrm{g} \cdot \mathrm{BDP} \cdot \mathrm{day}^{-1}\right)$ than those with lower levels of eNO at baseline $\left(0-200 \mu \mathrm{g} \cdot \mathrm{BDP} \cdot \mathrm{day}^{-1}\right)$.

There are a number of potential criticisms of the current study. Firstly, the range of doses of BDP to which patients were randomised did not include $1,000 \mu \mathrm{g} \cdot \mathrm{day}^{-1}$. This was because of earlier suggestions that not only were eNO measurements very sensitive to changes in ICS dose, but that the clinical benefits of ICS were limited at higher doses [31], even in patients with severe asthma [32]. Therefore, the current authors wished to address the possibility that there is a threshold for the anti-inflammatory effects of ICS within the lower dose range. Secondly, the study model which was employed i.e. withdrawal of ICS prior to beginning the randomised phase of the study [33], resulted in a significant number of patients whose asthma remained uncontrolled after randomisation. For ethical reasons these patients were re-allocated to receive $1,000 \mu \mathrm{g} \cdot \mathrm{day}^{-1}$. The analysis was on an intention-to-treat basis, and therefore included statistical adjustments for those patients who were changed to the higher dose. When analysed post-hoc as a separate treatment group, the patients receiving $1,000 \mu \mathrm{g} \cdot \mathrm{day}^{-1}$ did provide useful information: in this group eNO levels at week 8 were higher (mean eNO, 17.3 parts per billion (ppb) $(95 \% \mathrm{CI}, 11.1-23.5))$ than patients receiving $500 \mu \mathrm{g} \cdot \mathrm{day}^{-1}$ (mean eNO, $10.4 \mathrm{ppb}(95 \%$ CI, 4.4-16.4)). Because of selection bias the difference between the groups was not formally analysed. However, this suggests that despite higher doses of ICS, eNO levels remain elevated in a subset of patients with more severe asthma [34], reflecting ongoing airway inflammation in this subgroup, and confirming the need for higher doses of ICS. Finally, despite finding a linear relationship between eNO and the dose of ICS, eNO measurements were not able to distinguish between adjacent ICS doses consistently when assessed in pairwise comparisons, although eNO was better in this regard than all other measured parameters. This appears to be a feature of almost all dose-response studies for ICS, irrespective of the end point used, and with even larger numbers of patients [29, 30,35].

Nonspecific airway responsiveness appears to reflect airway inflammation even in the absence of ongoing symptoms and abnormal lung function [7]. Changes in AHR might therefore provide a useful measure by which the anti-inflammatory effects of ICS could be evaluated. However in the current study, there were no significant changes in AHR to hypertonic saline. This may reflect the low doses of ICS used or the relatively short duration of treatment. Other authors have reported contrasting results using alternative methodologies [27, 28, 35-37]. In general AHR to the direct bronchoconstrictors methacholine and histamine appears to be less sensitive than indirect bronchoconstrictors in detecting changes occurring with corticosteroid treatment [27, 38]. Unfortunately, the interpretation of many studies is made difficult because they have included patients with mild asthma and have used high doses of ICS [4].

The optimum approach to establishing patients on an appropriate dose of ICS has still not been defined. There are two questions of relevance. Firstly, does increasing the dose of ICS above a certain threshold result in greater efficacy? In the majority of patients only small increments in lung function are achieved when the dose of ICS is increased progressively [29, $30,35]$. This calls into question either the effectiveness of higher doses of ICS, or more likely, the validity of simple lung function measurements in this setting. Secondly, is it necessary to suppress airway inflammation completely in order to obtain optimum control, and how is this best assessed? Minimising airway responsiveness to adenosine monophosphate or methacholine (as a surrogate for airway inflammation [7]) appears to be dose-related $[27,36,37]$. When antiinflammatory therapy is tailored to reduce AHR, clinical outcomes are improved [39]. Unfortunately, repeated measurements of AHR are unsuited for routine clinical practice and it is unlikely that their widespread application will become commonplace. In contrast, eNO measurements are repeatable and easy to perform.

The current authors have recently shown that exhaled nitric oxide measurements may be used to predict deteriorating asthma control, and that they reflect changes in underlying airway inflammation [17]. These findings, together with the results of the present study, offer the possibility that repeated measurements of exhaled nitric oxide may be useful in guiding dose adjustments of inhaled corticosteroids in patients with persistent asthma. This requires further prospective investigation.

Acknowledgements. The authors would like to thank 3M Pharmaceuticals for the supply of study medications.

\section{References}

1. Barnes PJ. Efficacy of inhaled corticosteroids in asthma. J Allergy Clin Immunol 1998; 102: 531-538. 
2. Djukanovic R, Wilson JW, Britten KM, et al. Effect of an inhaled corticosteroid on airway inflammation and symptoms in asthma. Am Rev Respir Dis 1992; 145: 669-674.

3. van Rensen ELJ, Straathof KCM, Veselic-Charvat MA, Zwinderman AH, Bel EH, Sterk PJ. Effect of inhaled steroids on airway hyperresponsiveness, sputum eosinophils, and exhaled nitric oxide levels in patients with asthma. Thorax 1999; 54: 403-408.

4. van Grunsven PM, van Schayck CP, Molema J, Akkermans RP, van Weel C. Effect of inhaled corticosteroids on bronchial responsiveness in patients with "corticosteroid naïve" mild asthma: a metaanalysis. Thorax 1999; 54: 316-322.

5. du Toit JI, Anderson SD, Jenkins CR, Woolcock AJ, Rodwell LT. Airway responsiveness in asthma: Bronchial challenge with histamine and $4.5 \%$ sodium chloride before and after budesonide. Allergy Asthma Proc 1997; 18: 7-14.

6. NHLBI/WHO. NHLBI/WHO Workshop Report. Global initiative for asthma. Global strategy for asthma management and prevention, 1995. Publication No. 95-3695. Bethesda, MD, National Institutes of Health, 1995.

7. Sont JK, Han J, van Krieken JM, et al. Relationship between the inflammatory infiltrate in bronchial biopsy specimens and clinical severity of asthma in patients treated with inhaled steroids. Thorax 1996; 51: 496-502.

8. Haley KJ, Drazen JM. Inflammation and airway function in asthma. What you see is not necessarily what you get. Am J Respir Crit Care Med 1998; 157: $1-3$.

9. Foresi A, Bertorelli G, Pesci A, Chetta A, Olivieri D. Inflammatory markers in bronchoalveolar lavage and in bronchial biopsy in asthma during remission. Chest 1990; 98: 528-535.

10. Lipworth BJ. Airway and systemic effects of inhaled corticosteroids in asthma: dose response relationship. Pulm Pharmacol 1996; 9: 19-27.

11. Toogood JH, Lefcoe NM, Haines DSM, et al. A graded dose assessment of the efficacy of beclomethasone dipropionate aerosol for severe chronic asthma. J Allergy Clin Immunol 1977; 59: 298-308.

12. Kraan J, Koëter GH, van der Mark TW, et al. Dosage and time effects of inhaled budesonide on bronchial hyperreactivity. Am Rev Respir Dis 1988; 137: 44 48.

13. Kharitonov SA, Alving K, Barnes PJ. Exhaled nitric oxide measurements: recommendations. ERS Task Force Report. Eur Respir J 1997; 10: 1683-1693.

14. ATS. Recommendations for standardized procedures for the on-line and off-line measurement of exhaled lower respiratory nitric oxide and nasal nitric oxide in adults and children-1999. Official statement of the American Thoracic Society. Am J Respir Crit Care Med 1999; 160: 2104-2117.

15. Alving K, Weitzberg E, Lundberg JM. Increased amount of nitric oxide in exhaled air of asthmatics. Eur Respir J 1993; 6: 1368-1370.

16. Crater SE, Peters EJ, Martin ML, Andrew WM, Platts-Mills TAE. Expired nitric oxide and airway obstruction in asthma patients with an acute exacerbation. Am J Respir Crit Care Med 1999; 159: 806-811.

17. Jones $\mathrm{S}$, Kittelson $\mathrm{J}$, Cowan $\mathrm{J}$, et al. The predictive value of exhaled nitric oxide measurements in assessing changes in asthma control. Am J Respir Crit Care Med 2001; 164: 738-743.
18. Kharitonov SA, Yates DH, Barnes PJ. Inhaled glucocorticoids decrease nitric oxide in exhaled air of asthmatic patients. Am J Respir Crit Care Med 1996; 153: 454-457.

19. Jatakanon A, Lim S, Chung KF, Barnes PJ. An inhaled steroid improves markers of airway inflammation in patients with mild asthma. Eur Respir J 1998; 12: $1084-1088$.

20. Massaro AF, Gaston B, Kita D, Fanta C, Stamler JS, Drazen JM. Expired nitric oxide levels during treatment of acute asthma. Am J Respir Crit Care Med 1995; 152: 800-803.

21. ATS. American Thoracic Society. Standards for the diagnosis and care of patients with chronic obstructive pulmonary disease (COPD) and asthma. Am Rev Respir Dis 1987; 136: 225-244.

22. Iredale MJ, Wanklyn AR, Phillips IP, Krausz T, Ind PW. Non-invasive assessment of bronchial inflammation in asthma: no correlation between eosinophilia of induced sputum and bronchial responsiveness to inhaled hypertonic saline. Clin Exp Allergy 1994; 24 : 940-945.

23. Sterk PJ, Fabbri LM, Quanjer PH, et al. Airway responsiveness. Standardized challenge testing with pharmacological, physical and sensitizing stimuli in adults. Eur Respir J 1993; 6: Suppl. 16, 53-83.

24. Fahy JV, Liu J, Wong H, Boushey HA. Cellular and biochemical analysis of induced sputum from asthmatic and from healthy subjects. Am Rev Respir Dis 1993; 147: 1126-1131.

25. Silkoff PE, McClean P, Spino M, Erlich L, Slutsky AS, Zamel N. Dose-response relationship and reproducibility of the fall in exhaled nitric oxide after inhaled beclomethasone dipropionate therapy in asthma patients. Chest 2001; 119: 1322-1328.

26. Lim S, Jatakanon A, John M, et al. Effect of inhaled budesonide on lung function and airway inflammation - assessment by various inflammatory markers in mild asthma. Am J Respir Crit Care Med 1999; 159: 22-30.

27. Wilson AM, Lipworth BJ. Dose-response evaluation of the therapeutic index for inhaled budesonide in patients with mild-to-moderate asthma. $\mathrm{Am} \mathrm{J} \mathrm{Med}$ 2000; 108: 269-275.

28. Jatakanon A, Kharitonov S, Lim S, Barnes PJ. Effect of differing doses of inhaled budesonide on markers of airway inflammation in patients with mild asthma. Thorax 1999; 54: 108-114.

29. Busse WW, Brazinsky S, Jacobson K, et al. Efficacy response of inhaled beclomethasone dipropionate in asthma is proportional to dose and is improved by formulation with a new propellant. $J$ Allergy Clin Immnunol 1999; 104: 1215-1222.

30. Welch MJ, Levy S, Smith JA, Feiss G, Farrar JR. Dose-ranging study of the clinical efficacy of twicedaily triamcinolone acetonide inhalation aerosol in moderately severe asthma. Chest 1997; 112: 598-606.

31. Kamada AK, Szefler SJ, Martin RJ, et al. Issues in the use of inhaled glucocorticoids. Am J Respir Crit Care Med 1996; 153: 1739-1748.

32. Hummel S, Lehtonen L. Comparison of oral-steroid sparing by high-dose and low-dose inhaled steroid in maintenance treatment of severe asthma. Lancet 1992; 340: 1483-1487.

33. Gibson PG, Wong BJO, Hepperle MJE, et al. A research method to induce and examine a mild exacerbation of asthma by withdrawal of inhaled 
corticosteroid. Clin Exp Allergy 1992; 22: 525532.

34. Stirling RG, Kharitonov SA, Campbell D, et al. Increase in exhaled nitric oxide levels in patients with difficult asthma and correlation with symptoms and disease severity despite treatment with oral and inhaled corticosteroids. Thorax 1998; 53: 10301034.

35. Dahl R, Lundback B, Malo J-L, et al. A dose-ranging study of fluticasone propionate in adult patients with moderate asthma. Chest 1993; 104: 1352-1358.

36. Hofstra WB, Neijens HJ, Duiverman EJ, et al. Doseresponse over time to inhaled fluticasone propionate treatment of exercise- and methacholine-induced bronchoconstriction in children with asthma. Pediatr Pulmonol 2000; 29: 415-423.
37. Taylor DA, Jensen MW, Kanabar V, et al. A dosedependent effect of the novel inhaled corticosteroid ciclesonide on airway responsiveness to adenosine5-monophosphate in asthmatic patients. Am J Respir Crit Care Med 1999; 160: 237-243.

38. O'Connor BJ, Ridge SM, Barnes PJ, Fuller RW. Greater effect of inhaled budesonide on adenosine5-monophosphate induced bronchoconstriction in asthma. Am J Respir Crit Care Med 1992; 146: 560564.

39. Sont JK, Willems LNA, Bel EH, van Krieken JHJM, Vandenbroucke JP, Sterk PJ. Clinical control and histopathologic outcomes of asthma when using airway hyperresponsiveness as an additional guide to long-term treatment. Am J Respir Crit Care Med 1999; 159: 1043-1051. 